\title{
Ohran sopeuttaminen ilmastonmuutokseen geenivarojen ja genomiikan avulla (OHRASOPU)
}

\author{
Outi Manninen, Teija Tenhola-Roininen, Maria Erkkilä, Ari Rajala, Pirjo Peltonen-Sainio ja Marja Jalli \\ MTT Maa- ja elintarviketalouden tutkimuskeskus, 31600 Jokioinen, outi.m.manninen@mtt.fi
}

\section{Tiivistelmä}

MTT:1lä on meneillään kolmivuotinen MMM:n rahoittama hanke OHRASOPU. Tutkimushankkeen pitkän tähtäimen tavoite on varmistaa taloudellisesti kannattava ja ympäristöystävällinen ohranviljely muuttuvassa ilmastossamme. Tavoitteemme on edistää ohran geenivarojen hyödyntämistä lajikejalostuksessa. Selvitämme pohjoismaisen NordGen-geenipankin maatiaisohramateriaalin käyttöarvoa lajikejalostuksessa sopeuduttaessa ilmastonmuutokseen, erityisesti liittyen mahdollisiin eroihin typenkäytön tehokkuus- ja taudinkestävyysominaisuuksissa. Paikannamme ohran genomista em. ominaisuuksiin vaikuttavia kromosomialueita assosiaatiokartoituksen avulla sekä kehitämme lajikejalostukselle valintamerkkejä maatiaismateriaalista löytyvien positiivisesti vaikuttavien geenimuotojen hyödyntämiseksi jalostusohjelmissa. Hanke toteutetaan yhteistyössä Boreal Kasvinjalostus Oy:n ja NordGen-geenipankin kanssa.

Hankkeessa on aluksi lisätty 70 pohjoismaista maatiaisohraa ja 130 uutta ja vanhaa ohralajiketta yhdestä siemenestä, jotta päästään homogeeniseen ohramateriaaliin. Kaikki ohrat on genotyypitetty 3000 SNP (single nucleotide polymorphism) -merkillä. Ohrat olivat kesällä 2011 kenttäkokeessa, josta tehtiin kasvuaika ja lakoutumishavainnot sekä otettiin kasvustonäytteet tähkälletulo- ja tuleentumisvaiheessa typpianalyyseja varten. Kokeessa käytettiin kahta typpitasoa. Kenttäkoetulosten analysointi on vielä kesken.

Ohrat on tautitestattu verkko- ja rengaslaikun kestävyyden suhteen kasvihuoneessa ja/tai kentällä, jatkossa ohrat testataan kasvihuoneessa myös ohranruosteen sekä ohran tyvi- ja lehtilaikun kestävyyden suhteen. Keskimäärin lajike- ja maatiaispopulaatiot käyttäytyivät samansuuntaisesti testattuja taudinaiheuttajia vastaan. Enemmistö testattavasta aineistosta oli taudinaiheuttajille altista. Eniten kestävyyttä maatiaisista löytyi verkkolaikun laikkutyyppiä vastaan. Gammal Dansk (NGB15162) kesti ainoana maatiaisohrana hyvin kaikkia testattuja kasvitauteja. Ohralajikkeiden kauppaanlaskuvuodella ei ollut yhteyttä lajikkeiden taudinkestävyyteen.

Ohramateriaalin populaatiorakenteessa merkittävin asia oli tahoisuus eli kaksi- ja monitahoiset ohrat poikkeavat selvästi geneettisesti toisistaan. Kaksitahoisissa ohrissa maatiaiset ovat selvästi monimuotoisempia kuin lajikemateriaali, mutta monitahoinen maatiaismateriaali oli yllättävästi keskenään varsin samankaltaista. Alustavissa assosiaatioanalyyseissa olemme tunnistaneet verkkolaikun kestävyyteen liittyviä kromosomialueita. Merkittävin niistä näyttää osuvan samalle alueelle kromosomissa $6 \mathrm{H}$, jossa teemme etiopialaisesta ohrasta peräisin olevan suurivaikutteisen resistenssigeenin hienokartoitusta. Tästä resistenssigeenistä näyttää siis olevan lajike- ja maatiaismateriaalissa geenimuotoja eli alleeleita, jotka parantavat verkkolaikunkestävyyttä, mutta eivät kuitenkaan anna kovin vahvaa kestävyyttä sitä vastaan.

\section{Asiasanat}

Ohra, ilmastonmuutos, typenkäytöntehokkuus, taudinkestävyys, verkkolaikku, rengaslaikku, ohranruoste, single nucleotide polymorphism, SNP-merkit, assosiaatiokartoitus, populaatiorakenne

\section{Tausta}

Ilmastonmuutoksen tuomat haasteet 
Ilmastonmuutos tuo mukanaan uusia mahdollisuuksia mutta myös haasteita suomalaiselle kasvinviljelylle. ILMASOPU-hankkessa tehtyjen tutkimusten mukaan ilmaston lämpenemisen myötä on mahdollista viljellä nykyisiä päätuotantokasveja yhä pohjoisempana ja myös niiden satopotentiaalit kasvavat merkittävästi. Ohra tulee edelleen säilyttämään asemansa yhtenä merkittävimmistä Suomen peltoviljelykasveista.

Peltoviljelykasviemme tuotantokyvyn parantuminen ei ole itsestäänselvyys, vaan edellyttää ilmastonmuutoksen tuomien haasteiden määrätietoista ratkaisemista sekä ennakoivien sopeutumistoimien suunnittelua ja toimeenpanoa. Valtaosa sopeuttamistarpeista edellyttää kasvinjalostusta, jonka tuloksena onnistutaan tuottamaan yhä paremmin tulevaisuuden oloihin sopeutuneita lajikkeita. Keskeisimmät ohralajikkeiden sopeuttamishaasteet liittyvät kehityksen rytmitykseen, taudinkestävyyteen ja ravinteidenkäytön tehostamiseen.

Kasvintuhoojien merkitys suomalaisessa peltoviljelyssä on jatkuvassa muutoksessa. Suomalaisen tutkimuksen mukaan keskilämpötilan kohoaminen yhdellä asteella tuo mukanaan yhden tautitorjuntakerran lisää vuodessa. Kymmenessä vuodessa (1996-2006) on kasvitautien torjuntaan käytettyjen tehoaineiden käyttö Suomessa kaksinkertaistunut (fungisidien myynnin arvo vuonna 2006 15,4 milj €). Suomen Rehun useampivuotisten viljatutkimusten mukaan pelkästään ohra-alasta käsitellään vuosittain kasvitautien torjuntaaineilla noin $30 \%$. Torjunta-aineiden käytöstä aiheutuneet kustannukset ja ympäristökuormitus voitaisiin välttää viljelemällä taudinkestäviä lajikkeita. Samalla saavutettaisiin samat hyödyt kuin torjunta-aineita käyttämällä: korkeampi satotaso, isompi jyväkoko sekä parempi ravinteiden talteenotto. Kasvien geeneihin perustuva taudinkestävyys on ympäristö-ystävällinen tapa hallita kasvitauteja, eikä kestävän lajikkeen viljely aiheuta lisäkustannusta viljelijälle.

\section{Kasvinjalostus perustuu geenivarojen hyödyntämiseen}

Ohranjalostuksen perusta on paikallisiin ilmasto- ja viljelyolosuhteisiin sopeutuneessa ohramateriaalissa. Meillä menestyvien ohralajikkeiden tulee olla sopeutuneita pitkän päivän olosuhteisiin. Ohran lajikejalostukseen voidaan tuoda hallitusti uutta perinnöllistä muuntelua esijalostusohjelmien kautta. Esijalostusohjelmassa voidaan esimerkiksi pyrkiä hyödyntämään geenipankeissa säilöttyjen maatiaiskantojen monimuotoisuutta taudinkestävyyden, typenkäytön tehokkuuden ja kasvurytmin suhteen. NordGengeenipankissa on tallennettuna yhteensä 145 pohjoismaista kerättyä maatiaisohrakantaa, jotka ovat sopeutuneet pohjoisiin pitkän päivän olosuhteisiin. Maatiaisohra-aineiston kehitysrytmistä, typenkäytön tehokkuudesta ja taudinkestävyydestä ei ole kattavaa selvitystä. Maatiaisia nopeammin uutta perinnöllistä muuntelua voidaan tuoda jalostusohjelmaan käyttämällä intensiiviseen viljelyyn jo sopeutuneita ohragenotyyppejä eli lajikkeita. Eteläisempiä eli myöhäisempiä lajikkeita käytettäessä on hyvä ymmärtää, miten ko. genotyypit käyttäytyvät meidän pitkän päivän olosuhteissamme. Typenkäytön tehokkuudessa havaittuja eroja lajikkeiden välillä voidaan myös pyrkiä hyödyntämään jalostuksessa. OHRASOPUtutkimuksen tarkoitus on selvittää pohjoismaisten maatiaisohrien ja laajan lajikemateriaalin käyttöarvoa sopeutettaessa suomalaista ohraa ilmastonmuutokseen.

\section{Kasvigenomiikan työkalut nopeuttavat lajikejalostusta}

Kasvigenomiikka tarjoaa kasvinjalostukselle lajikekehitystä nopeuttavia työkaluja. Näitä ovat esimerkiksi DNA-tason valintamerkit, joiden avulla jalostaja voi karsia jalostusmateriaalista epäkelvot yksilöt pois jo ennen ominaisuuksien testaamista kenttäkokeissa. Valintamerkkejä on tuotettu viimeiset 15 vuotta kytkentäanalyysiin perustuvalla geenikartoituksella. MTT:llä on tehty tällaista geenikartoitustyötä mm. ohralla, kauralla ja rukiilla. Ongelmana on kuitenkin se, että kartoitustyö perustuu aina vain harvoihin vanhemmaisgenotyyppeihin eikä tulosten sovellettavuus kaikissa tapauksissa ole jalostusmateriaalissa kovin hyvä. Viime vuosina usealle kasvilajille, joukossa ohra, on kehitetty suuri määrä koko genomin kattavia SNP-merkkjä, jotka mahdollistavat ns. assosiaatiokartoituksen. Assosiaatiokartoitus perustuu DNA-merkin ja lähellä samassa kromosomissa sijaitsevien geenien väliseen kytkentäepätasapainoon populaatiossa. Assosiaatiokartoituksessa voidaan käyttää lähtömateriaalina esimerkiksi laajaa geenivara-aineistoa ja menetelmän avulla voidaan paikantaa uusia hyötygeenejä ja -alleeleita. Menetelmän avulla löydettävät valintamerkit ovat tarkempia ja paremmin sovellettavissa lajikejalostukseen kuin perinteisellä kytkentäanalyysillä löydetyt merkit. OHRASOPU-tutkimuksessa selvitämme typenkäytön tehokkuuden ja taudinkestävyyden perinnöllistä taustaa sekä kehitämme lajikejalostusta nopeuttavia valintatyökaluja ohranjalostukseen.

\section{Materiaali ja menetelmät}


Hankkeessa käytetty ohramateriaali (pohjoismaiset maatiaiset ja setti eurooppalaisia lajikkeita, yht. 195 ohragenotyyppiä) on lisätty yhdestä siemenestä ensin kasvihuoneella kahdesti ja sitten pellolla kesällä 2010. Ohran lehdistä eristetyt DNA-näytteet lähetettiin SNP-genotyypitystä varten USA:han. Kaikki ohragenotyypit on SNP-tyypitetty yhteensä 1532:1la SNP-merkillä. Osa tyypityksistä oli jo valmiina meneillään olevassa Exbardiv-hankkeessa, osa teetettiin USA:ssa Kalifornian yliopistossa (UCLA) kevättalvella 2011.

Ohragenotyyppien typenkäytön tehokkuutta tutkitaan vuosina 2011 ja 2012 kerranteellisin peltokokein. Ensimmäisen vuoden kokeet kylvettiin Jokioisilla 9.-11. toukokuuta 2011. Kokeessa oli kaksi lannoitustasoa: 35 ja $70 \mathrm{~kg} \mathrm{~N} / \mathrm{ha}$, sekä yhdeksästä lajikkeesta lisäksi lannoittamaton koejäsen.

Lannoituskäsittelyt toistettiin kolmena kerranteena. Koeruudun pituus oli 2,5 m. Kasvukauden aikana seurattiin lajikkeiden kasvurytmiä (lippulehti, tähkälletulo ja keltatuleentuminen). Kasvuston pituus mitattiin ruuduittain, sekä havainnoitiin lakoutuminen. Kasvustonäytteet kerättiin tähkälletulovaiheessa (50 kasviyksilöä per ruutu) ja satonäytteet ennen puintia (50 kasviyksilöä per ruutu). Syksyn ja talven aikana määritetään kasvustonäytteistä biomassa ja typpipitoisuus.

Ohramaatiaisten sekä lajikkeiden taudinkestävyyttä tutkittiin kasvihuone- ja kenttäkokeissa. Kasvihuonekokeissa testattiin genotyyppien ohraverkkolaikun kestävyyttä yksittäisiä laikku- ja verkkotyypin isolaatteja vastaan.

\section{Tulokset ja tulosten tarkastelu}

SNP-merkkidataa on käytetty tutkittavan ohramateriaalin diversiteetin ja populaatiorakenteen selvittämiseen. Kaksi- ja monitahoiset ohrat eroavat selvästi toisistaan (Kuva 1). Kuvista 2 ja 3 selviää erikseen monitahoisissa ja kaksitahoisissa ohrissa SNP-merkeillä havaittu perinnöllinen vaihtelu. Monitahoisissa ohrissa maatiaiset muodostavat yllättäen selvän ryhmittymän ja poikkeavat toisistaan paljon vähemmän kuin lajikkeet.

Kuva 1. Kaikki Ohrasopu-hankkeen ohrat

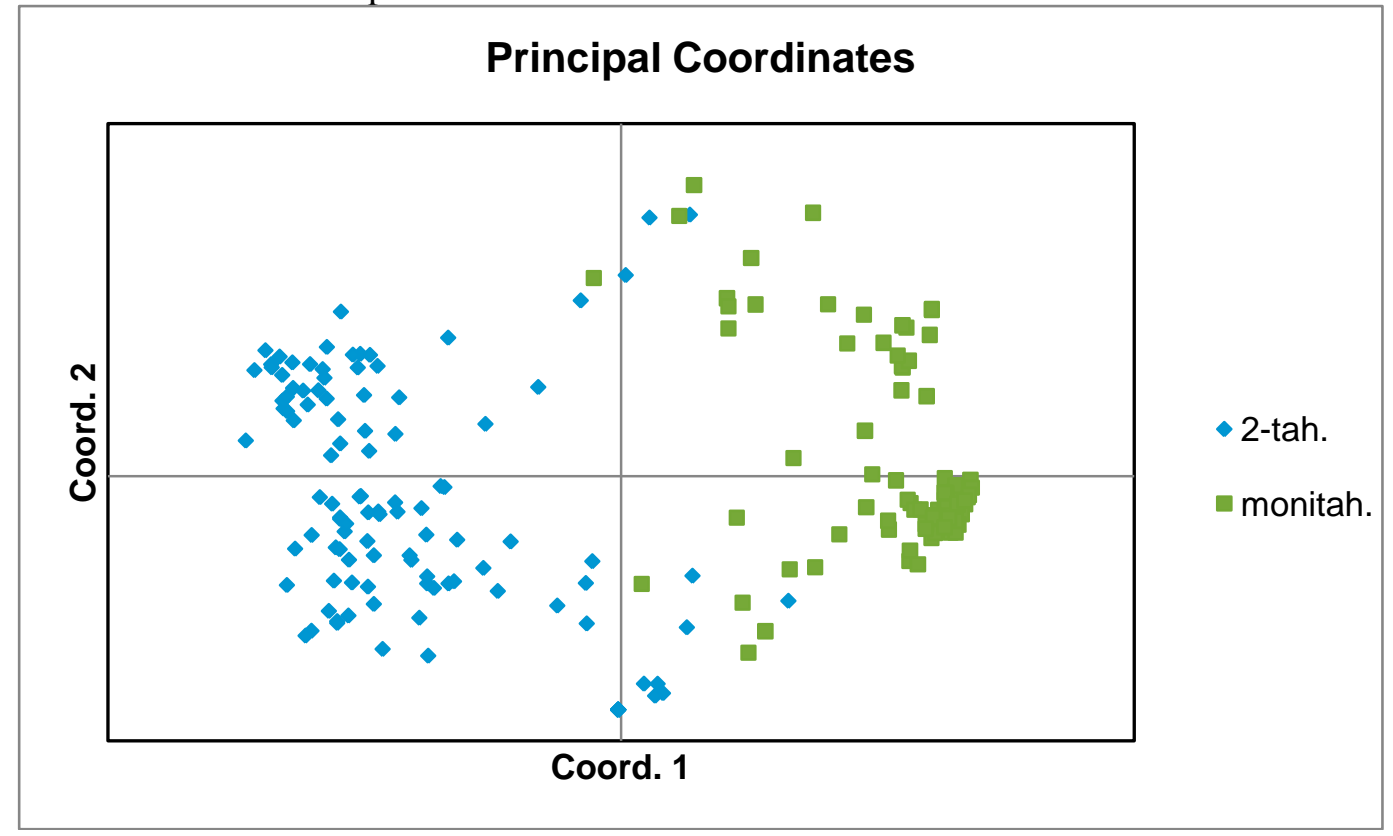

Kuva 2. Monitahoinen ohra 


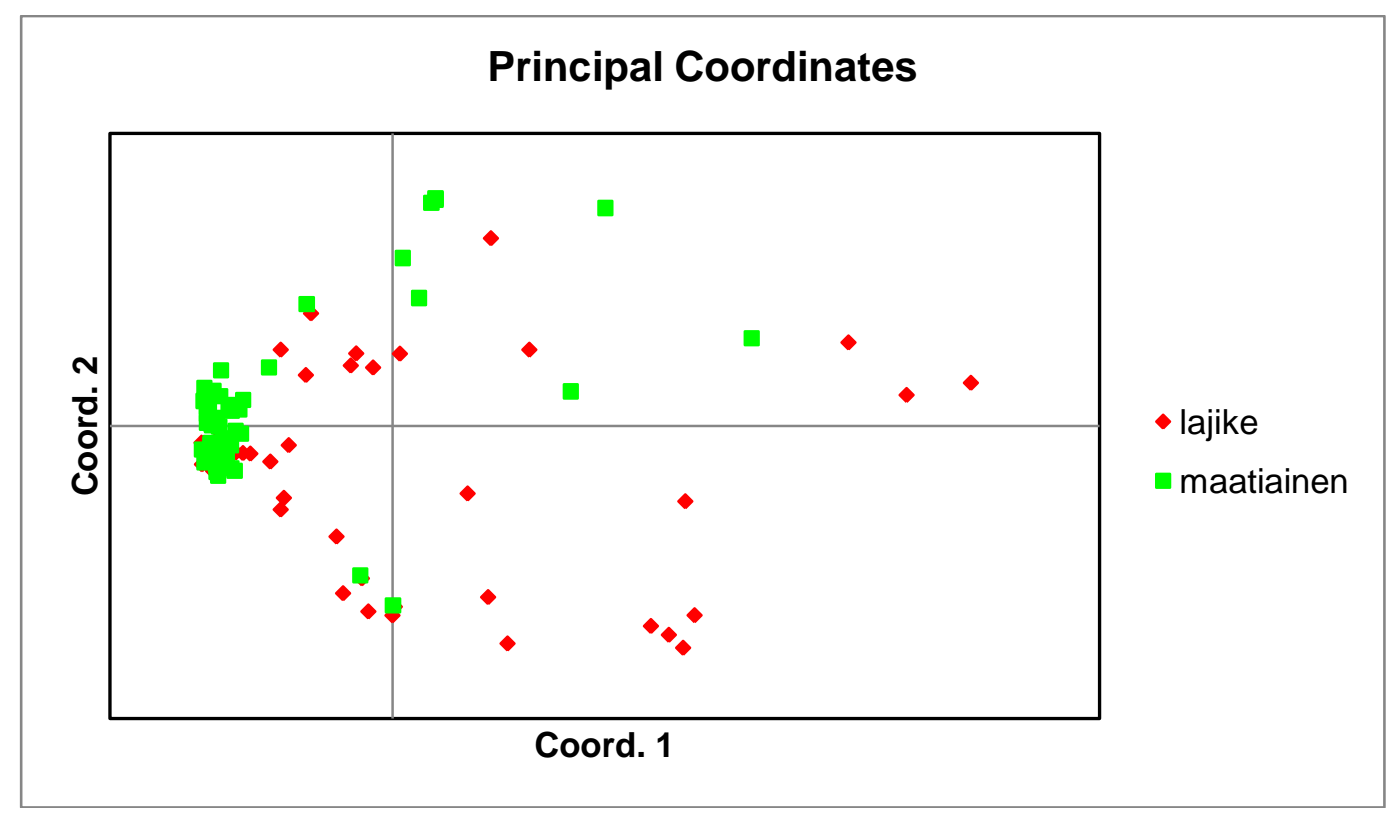

Kuva 3. Kaksitahoinen ohra

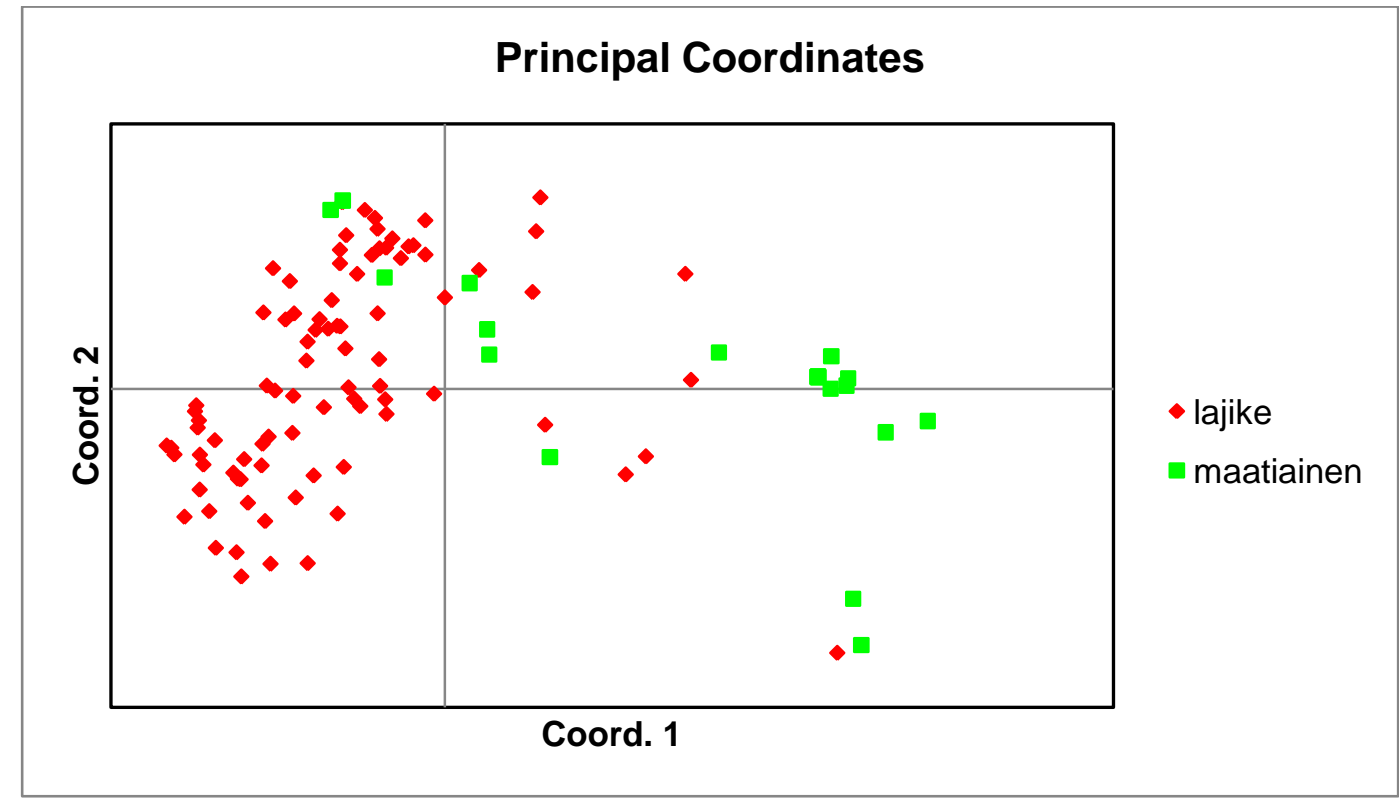

Ensimmäisen vuoden kenttäkoe on viety onnistuneesti läpi, mutta tulosten analysointi on vielä kesken ja kemialliset analyysit tekemättä. Satonäytteistä määritetään parhaillaan fytomassa (koko kasvustomassa), jyvämassa, tuhannen jyvän paino, satoindeksi, sekä jyvän ja oljen typpipitoisuus. Analyysitulosten pohjalta voidaan määrittää kasvuston kokonaistypen otto, typen jakautuminen sato-osaan ja laskennallisesti erilaisia typpiparametreja.

Keskimäärin lajike- ja maatiaispopulaatiot käyttäytyivät samansuuntaisesti testattuja taudinaiheuttajia (verkkolaikun verkko- ja laikkutyypit sekä rengaslaikku)vastaan. Enemmistö testattavasta aineistosta oli taudinaiheuttajille altista. Eniten kestävyyttä maatiaisista löytyi verkkolaikun laikkutyyppiä vastaan. Gammal Dansk (NGB15162) kesti ainoana maatiaisohrana hyvin kaikkia testattuja kasvitauteja. Ohralajikkeiden kauppaanlaskuvuodella ei ollut yhteyttä lajikkeiden taudinkestävyyteen. Taudinkestävyystestejä jatketaan vielä ohranrengaslaikkua sekä ohrantyvi- ja lehtilaikkua vastaan kasvihuoneessa. 
Alustavissa assosiaatioanalyyseissa olemme tunnistaneet verkkolaikun kestävyyteen liittyviä kromosomialueita. Merkittävin niistä näyttää osuvan samalle alueelle kromosomissa $6 \mathrm{H}$, jossa teemme etiopialaisesta ohrasta peräisin olevan suurivaikutteisen resistenssigeenin hienokartoitusta. Tästä resistenssigeenistä näyttää siis olevan lajike- ja maatiaismateriaalissa geenimuotoja eli alleeleita, jotka parantavat verkkolaikunkestävyyttä, vaikka eivät aina anna täydellistä kestävyyttä sitä vastaan.

\section{Johtopäätökset}

Olemme löytäneet tutkimastamme ohramateriaalista (laaja lajikemateriaali ja pohjoismaiset maatiaisohrat) verkkolaikun ja rengaslaikun kestäviä genotyyppejä, joita voidaan hyödyntää taudinkestävyysjalostuksessa. Olemme alustavasti paikantaneet verkkolaikunkestävyyteen vaikuttavia kromosomialueita, joilla sijaitsevia SNP-merkkejä voidaan käyttää valintatyökaluina taudinkestävyysjalostuksessa. Jatkossa saamme tuloksia myös tyvi- ja lehtilaikun sekä ohranruosteen kestävyyden suhteen. Kenttäkokeen pohjalta tulemme määrittämään kasvuston kokonaistypen oton, typen jakautumisen sato-osaan ja laskennallisesti erilaisia typpiparametreja. Käytämme assosiaatiokartoitusta myös näihin ominaisuuksiin vaikuttavien geenien paikantamisessa sekä valintamerkkien kehittämisessä. 